\title{
Optimal Obfuscation: Democracy and Trade Policy Transparency
}

\author{
DANIEL Y. KONO University of California at Davis
}

\begin{abstract}
$A$
growing body of research shows that democracies have more liberal trade policies than do autocracies. I argue, in contrast, that democracy has contradictory effects on different types of trade policies because electoral competition generates more information about some than about others. It generates considerable information about policies whose effects on consumer welfare are easy to explain to voters, but less information about policies whose effects are more complex. By increasing the transparency of some policies relative to others, democracy induces politicians to reduce transparent trade barriers but also to replace them with less transparent ones. I test this hypothesis by examining the impact of democracy on tariffs, "core" nontariff barriers (NTBs) such as quotas, and "quality" NTBs such as product standards in 75 countries in the 1990s. I find that democracy leads to lower tariffs, higher core NTBs, and even higher quality NTBs. I conclude that democracy promotes "optimal obfuscation" that allows politicians to protect their markets while maintaining a veneer of liberalization.
\end{abstract}

D oes democracy promote free trade? The global rise of democracy makes this question practically as well as theoretically important. If the answer is yes, then the spread of democracy will foster economic integration, which may in turn promote economic development (Frankel and Romer 1999) and reduce the likelihood of war (Polachek 1980). This was clearly the Clinton Administration's hope when it claimed that that "Promoting democracy does more than foster our ideals. It advances our interests.... Democracies create free markets that offer economic opportunity [and] make for more reliable trading partners" (The White House 1996, 2). Although such rhetoric is easy to dismiss, it is in this case backed by empirical research: studies show that democracies trade more than autocracies (Bliss and Russett 1998), have lower tariffs (Milner and Kubota 2005), and are more likely to conclude liberalizing trade agreements (Mansfield, Milner, and Rosendorff 2002). In fact, the finding that democracy promotes trade openness is among the most robust in the field of international political economy.

There is good reason to expect this to be so. Votersas-consumers prefer liberal trade policies that lower prices and raise real incomes. Democratic politicians need votes to stay in power. Competition for votes should thus drive democratic leaders toward liberal policy positions. However, while this argument is intuitively appealing, it assumes that voters-as-principals have sufficient information to discipline politiciansas-agents. In reality, this may not be true, in which case democratic leaders have few incentives to liberalize trade. Moreover, politicians may be able to manipulate the flow of information by choosing policies,

\footnotetext{
Daniel Y. Kono is Assistant Professor, Department of Political Science, University of California at Davis, One Shields Avenue, Davis, CA 95616-8682 (dykono@ucdavis.edu).

I am especially grateful to Bob Jackman, Jeannette Money, and Gabriella Montinola for reading and commenting on multiple drafts of this paper. I also thank David Bearce, Christina Davis, Tim McKeown, Lee Sigelman, Bob Taylor, and three anonymous reviewers for the APSR for helpful comments, and Greg Love for research assistance. Any errors are, of course, my own.
}

such as technical barriers to trade, whose effects on consumer welfare are harder to discern than those of tariffs. If electoral concerns lead politicians to practice such "optimal obfuscation" (Magee, Brock, and Young 1989), then democracy may not affect the level of trade protection at all. Rather, it may simply alter its form, causing politicians to replace transparent trade barriers with less transparent ones.

The practice of obfuscation would have important implications for several scholarly and policy debates. First, it would force us to rethink the relationship between democracy and trade openness. If democracies liberalize with one hand but protect, surreptitiously, with the other, then the net impact of democracy on trade policy is unclear. Second, obfuscation would cast doubt on the common assertion that democracy leads to efficient policies (Becker 1983; Wittman 1989). If obfuscation leads to complex policies, and if complex policies are inefficient-as they often are-then democracy might well produce policy inefficiency. Finally, the practice of obfuscation would challenge the conventional wisdom concerning democracy and policy transparency. Most scholars believe that democracies provide more policy transparency than autocracies (Bueno de Mesquita et al. 2003; Rosendorff and Vreeland 2004). If obfuscation is prevalent, however, then the spotlight of electoral competition may lead politicians to provide, not more information, but more creative efforts to cover their tracks.

\section{DEMOCRACY AND TRADE POLICY}

The claim that democracy promotes trade liberalization rests on three propositions. First, all governments face interest-group demands for protection and are responsive to these pressures in some degree. Second, mass publics prefer more liberal trade policies than would be produced by interest-group pressures alone. Third, democratic governments are more responsive than autocratic ones to popular pressures. All three propositions are reasonable. The salience of interestgroup demands across a wide variety of countries has been demonstrated by "demand-side" research 
on trade policy (Lee and Swagel 1997). The claim that mass publics prefer liberal trade policies is both theoretically defensible-voters-as-consumers want cheap imports that raise their real incomes-and supported by public-opinion research on both developed and developing countries (Baker 2003; Herrmann, Tetlock, and Diascro 2001). Finally, the greater responsiveness of democratic leaders to popular pressures is inherent in the definition of democracy. Of course, it may not be the case that all interest groups want protection, that mass publics want completely free trade, or that democratic leaders are perfectly responsive to the electorate's preferences. However, as long as voters prefer more liberal policies than interest-group pressures alone would produce, and democratic leaders are more sensitive to voters than their autocratic counterparts, democracies should be more liberal than autocracies.

Mansfield, Milner, and Rosendorff (2002) qualify this argument by noting that voters have imperfect information about domestic trade policies. This informational asymmetry creates problems for both voters and governments. If voters cannot observe trade policy directly, they may be exploited by governments that promise to liberalize trade but do not. Conversely, if governments cannot prove that their policy declarations are more than cheap talk, then they may not reap the electoral benefits of trade liberalization. Democratic leaders thus have greater incentives to liberalize trade only if trade policy can be made transparent.

Mansfield, Milner, and Rosendorff (2002) argue that international agreements provide policy transparency because protectionist treaty violations lead to highly publicized international disputes. Without disputing this point, I argue that international agreements are not the only means to greater information about domestic trade policies. Democratic political competition also generates information because, if governments adopt welfare-reducing policies, their opponents have incentives to point this out. Democracy thus enfranchises and informs voters-as-consumers and should thus provide a double impetus for trade liberalization.

Democracy may not cause liberalization, however, because political competitors do not provide information indiscriminately. Informing the public is costly (Baba 1997): during the 2004 U.S. presidential campaign, for example, the two leading candidates spent \$575 million on television advertising alone (Todd 2004). Because resources are scarce, rational politicians seek the most informational bang for their buck, which means attacking policies whose costs can be explained quickly, easily, and cheaply. Political competition thus generates biased information: it informs voters about protectionist measures whose effects on consumer welfare are simple but tells them little about measures whose effects are more complex. Democracy thus reduces politicians' incentives to use simple, transparent trade barriers but increases incentives to employ complex, opaque ones.

This argument assumes that differences in policy complexity lead, via the political process, to differ- ences in policy transparency. Because this assumption is crucial, I develop it next before formalizing my argument.

\section{POLICY COMPLEXITY AND POLICY TRANSPARENCY}

Trade policy analysts distinguish three broad forms of protection: tariffs, "core" nontariff barriers (NTBs), and "quality" NTBs. Tariffs are import taxes. Core NTBs encompass both price control measures such as antidumping and countervailing duties and quantity control measures such as import licenses, quotas, and voluntary export restraints (VERs). Quality NTBs are product standards enforced through labeling requirements, packaging requirements, inspection, testing, and certification requirements, quarantines, and outright prohibitions. Although the three measures are similar in that all impede trade, they differ in that some have more complex effects on consumer welfare than do others.

Tariffs are simply taxes that generate no benefits for consumers. Their effects are thus straightforward: a $20 \%$ ad valorem tariff raises import prices by $20 \%$. In contrast, core NTBs have more complex effects. Although quotas and VERs, like tariffs, unambiguously hurt consumers by raising import prices, they do so indirectly by restricting import supply. As a consequence, it is hard for consumers to say how much these measures raise prices: even economists cannot calculate "tariff equivalents" of NTBs with precision. ${ }^{1}$ Finally, the welfare effects of quality NTBs are most complex of all. As with core NTBs, the price effects are hard to estimate. In addition, however, quality NTBs may have positive nonprice effects: they may lead to safer products, reduce the risk of pest infestations, stop sea turtle slaughter, and so on. These benefits, like the costs, are hard to measure: perhaps, for example, Mexican avocados do carry fruit flies-as both the U.S. government and California avocado growers claimed for years (Plume 1996) - but most consumers lack the expertise to make such judgments on their own. They can read expert studies, but if the government and opposition present conflicting evidence, then consumers must evaluate this research to determine who is telling the truth. Most consumers have neither the time nor the expertise for such evaluations.

Tariffs, core NTBs, and quality NTBs can thus be ranked according to the complexity of their effects on consumer welfare: the effects of tariffs are simple, those of core NTBs are more complex, and those of quality NTBs are most complex of all. Politicians who wish to challenge government policies understand these differences and take them into account when deciding how to allocate scarce resources. It is easy, and hence cheap, to explain the costs of tariffs to voters: the claim that "the government's 40 percent auto tariff raises auto prices by 40 percent" can be easily conveyed in a

\footnotetext{
${ }^{1}$ Hence the absence of continuous multidimensional measures of trade policy.
} 
30-second sound bite. It is more difficult to explain that a VER on autos of 250,000 units raises auto prices: the sound bite would need to last longer than 30 seconds, and it is not clear how effective this economics lecture would be, especially if politicians cannot say how much auto prices have risen. It is most difficult and most expensive to explain the net costs of quality NTBs: politicians must first explain complex price effects and then present evidence that the consumer benefits are lower than the government claims. For politicians with limited budgets, this is not a battle worth fighting. Costbenefit calculations thus lead political competitors to attack some policies but not others. It is politically profitable to challenge tariffs because the cost of informing voters is low. It is less profitable to attack core NTBs because the cost of informing voters is higher. It is least profitable to contest quality NTBs because the cost of persuading voters that such measures hurt consumer welfare is very high.

Governments understand their competitors' incentives to challenge their policies and respond accordingly. They are reluctant to use tariffs because their opponents will inform voters, who will punish their governments at the polls. They are more inclined to use core NTBs, which are less likely to be exposed. They are most inclined to use quality NTBs, which the opposition will probably not contest and which will thus go unnoticed by voters. Differences in the complexity of different trade policy instruments thus lead to differences in policy transparency, and the latter in turn affect the relative incentives to employ different forms of protection.

For two reasons, the incentives to employ less transparent protection grow as the polity becomes more democratic. First, voter information matters only to the extent that voters do, and the importance of voters rises with the competitiveness of the political system. ${ }^{2}$ Second, voter information-and the biased nature of this information-is itself a product of democratic competition. Pure autocracy generates no information; hence voters in autocracies are uniformly uninformed about all types of protection. Democracy leads to greater information, but it also increases disparities in voter knowledge about different forms of protection. Democracy thus produces asymmetries in policy transparency even as it increases the political salience of these asymmetries. For both of these reasons, democracy reduces the incentives to employ tariffs but increases the incentives to employ less transparent NTBs.

This informal argument leaves two questions unresolved. First, does regime type affect the absolute or simply the relative incentives to use different trade barriers? This question is important because democracy could conceivably increase the attractiveness of NTBs relative to tariffs while reducing all protection in absolute terms. Second, why would any kind of government

\footnotetext{
${ }^{2}$ By "voters" I mean people who could vote if elections were held. To the extent that autocrats can either not hold or rig elections, they have less need to take voter preferences into account.
}

employ tariffs instead of less transparent NTBs? Although autocratic leaders depend less than democratic ones on public support, they also have nothing to gain by alienating their publics. Hence, unless they exist in a complete informational vacuum, autocrats, like democrats, have incentives to court both popular and interest-group support by employing less transparent measures. To resolve these questions, I now develop a decision-theoretic model that clarifies the conditions under which governments employ different trade policy instruments.

\section{DEMOCRACY AND THE VARIETY OF TRADE POLICIES}

I assume that all politicians want primarily to stay in power. This requires two things. First, they need public support, although the requisite level of support varies across regime types. Politicians in competitive democracies need the support of a majority of voters, while those in less democratic countries need less because they can rig elections (or not hold them), ban or intimidate the opposition, forcibly repress the citizenry, and so on. Because political competition is a matter of degree, I assume that the importance of voter preferences rises monotonically with the competitiveness of the political system. Second, all politicians need money, although the reasons for this also vary across regime types. Democratic politicians need money primarily to finance campaigns, whereas autocratic politicians need money to maintain a coercive apparatus and to buy off potential opposition. Politicians can raise money in two ways: directly, through tariff revenues, or indirectly, by supplying protectionism of any kind in exchange for interest-group contributions. These assumptions imply a modified Grossman-Helpman (1994) political support function of the following form:

$$
G(t, c, q)=C(t, c, q)+R(t, c, q)+D V(t, c, q),
$$

where $G$ is government utility, $C$ is the sum of interestgroup contributions, $R$ is tariff revenue, $D$ is the country's degree of democracy, $V$ is voter support, $t$ is the tariff level, and $c$ and $q$ are levels of core and quality NTB protection, respectively. $D$ ranges from 0 to 1 , where 0 indicates pure autocracy and 1 indicates perfect democracy. $t, c$, and $q$ also range from 0 to 1 , where 0 indicates no protection and 1 indicates prohibitive protection. This function resembles Grossman and Helpman's in that the government maximizes a weighted sum of money and voter support. It differs in that (1) it includes tariff revenue as well as interest-group contributions, ${ }^{3}$ (2) the weight attached to voters increases with the degree of democracy, (3) the government

\footnotetext{
${ }^{3}$ In Grossman and Helpman's model, tariff revenues are redistributed uniformly to voters and are thus included in voter welfare rather than as a source of government finance. This assumption makes sense for democracies but less sense for autocracies, where governments are more likely to use tariff revenues for clientilistic or repressive purposes.
} 
has three substitutable protectionist instruments, and (4) voter support is based on imperfect information about trade policies. Because all governments have the same objective function, the only thing distinguishing democracies from autocracies is the weight each attaches to voter support.

I assume that interest-group contributions rise with the level of protection and that interest groups are indifferent to the form of protection: that is, the three instruments are perfect substitutes for the purpose of raising contributions. Each instrument offers diminishing marginal returns with respect to both itself and the others-that is, returns to tariffs fall as NTBs rise and vice-versa-because, when protectionism of any kind is high, then all types of protection yield low marginal returns to interest-group profits and contributions. At the extreme, if NTBs are prohibitive, then interest groups offer nothing in exchange for additional tariffs and vice-versa. The contribution function is

$C(t, c, q)=t^{\theta}+c^{\theta}+q^{\theta}+(t c q)^{\theta}-\left[(t c)^{\theta}+(t q)^{\theta}+(c q)^{\theta}\right]$,

where $\theta$ is a constant, $\theta \in(0,1)$. The expression in brackets captures the negative relationship between returns to each instrument and the level of the other and ensures that a prohibitive level of any instrument generates the same amount of contributions as prohibitive levels of all three. Contributions range from 0 to 1 .

The relationship between the tariff rate and tariff revenue is hump-shaped because at some point, additional tariffs depress imports by so much that revenues fall. Tariff revenues thus rise with the tariff rate until the revenue-maximizing tariff is reached, then return to zero as tariffs become prohibitive. Revenues fall continuously with NTBs because the latter depress imports. The tariff revenue function is

$$
R(t, c, q)=(1-c)(1-q)\left(t-t^{\rho}\right),
$$

where $\rho$ is a constant, $\rho>1$, that determines the elasticity of tariff revenues to the tariff rate. This elasticity approaches unity when $\rho$ approaches infinity but approaches zero as $\rho$ approaches one. ${ }^{4}$ Tariff revenues thus range from 0 to 1 .

Voter support is maximized when trade is completely free and minimized when protection of any kind is prohibitive. Hence, when protection is prohibitive, its form is irrelevant because it is so easy to discredit the government's policies that the opposition always chooses to do so. Intuitively, explaining the costs of even quality NTBs is easy when these barriers are prohibitive: politicians need only point out that importing is impossible, and it should be easy to convince voters that health and safety concerns cannot justify autarkic policies. The form of protection is not irrelevant, however, when it falls short of prohibitive levels. In this case, the opposition finds it politically profitable to attack tariffs, less profitable to attack core NTBs, and even

\footnotetext{
${ }^{4}$ I refer to the average elasticity over the "normal" or upwardsloping part of the tariff-revenue curve, which also grows larger along with $\rho$.
}

less profitable to attack quality NTBs. Tariff hikes thus reduce voter support by more than equivalent increases in core NTBs, which in turn reduce support by more than equivalent increases in quality NTBs. At some point, these relationships reverse - the marginal political costs of quality NTBs become greater than those of core NTBs, which in turn become greater than those of tariffs-because all three instruments eventually drive voter support to zero. Formally, voter support is

$$
\begin{aligned}
V(t, c, q)= & 1-t^{\alpha}-c^{\beta}-q^{\delta}-t^{\alpha} c^{\beta} q^{\delta} \\
& +\left[t^{\alpha} c^{\beta}+t^{\alpha} q^{\delta}+c^{\beta} q^{\delta}\right],
\end{aligned}
$$

where $\alpha, \beta$, and $\delta$ are constants, $1<\alpha<\beta<\delta$. Tariffs have a smaller exponent than do core NTBs, and core NTBs have a smaller exponent than do quality NTBs, because political competition generates asymmetric information about these instruments. Moreover, because $V$ is multiplied by $D$ in the government's objective function, the informational differences between these instruments grow larger - as does the cost of using any form of protection-as the degree of democracy rises. As in the contribution function, the term in brackets captures the fact that an increase in any type of protection reduces the marginal effects of the others. Voter support ranges from 0 to 1 .

Putting the contribution, revenue, and voter support functions together yields the following political support function:

$$
\begin{aligned}
G(t, c, q)= & \overbrace{t^{\theta}+c^{\theta}+q^{\theta}+(t c q)^{\theta}-\left[(t c)^{\theta}+(t q)^{\theta}+(c q)^{\theta}\right]}^{\text {contributions }} \\
& +\overbrace{\left(\begin{array}{c}
1-c)(1-q)\left(t-t^{\rho}\right) \\
\text { tariff revenue }
\end{array}\right.} \\
& +D(\underbrace{1-t^{\alpha}-c^{\beta}-q^{\delta}-t^{\alpha} c^{\beta} q^{\delta}+t^{\alpha} c^{\beta}+t^{\alpha} q^{\delta}+c^{\beta} q^{\delta}}_{\text {voter support }}) .
\end{aligned}
$$

Maximizing $G$ with respect to $t, c$, and $q$ yields no closed-form solution: the relationship between $D$ and politically optimal levels of $t, c$, and $q$ depends on the relative magnitude of $\theta, \rho, \alpha, \beta$, and $\delta$. I thus performed simulations, maximizing $t, c$, and $q$ for 748,440 combinations of the other parameters. ${ }^{5}$ Because $\theta \in(0,1)$, I allowed $\theta$ to vary from .1 to .9 in increments of $.1 . \rho$ must be greater than 1 and has no theoretical maximum; I allowed it to range from 1.1 to 10 in increments of .1. $\alpha$, $\beta$, and $\delta$ ranged from 2 to 10 in increments of 1 , subject to the constraint that $\alpha<\beta<\delta$. Democracy varied from 0 to 1 in increments of .1.

These simulations generated two types of outcomes: one in which increases in democracy had asymmetric effects on different trade barriers and one in which such increases led to liberalization of all three. Which outcome prevailed depended mainly on the value of $\rho$, which determines tariff revenue elasticities. Representative simulation results for both types of outcomes for $\theta=.5, \alpha=2, \beta=3$, and $\delta=4$ are shown in Figure 1 .

\footnotetext{
${ }^{5}$ Simulations were performed with Mathematica 5.2.
} 


\section{FIGURE 1. Democracy and Politically Optimal Protection: Simulation Results}

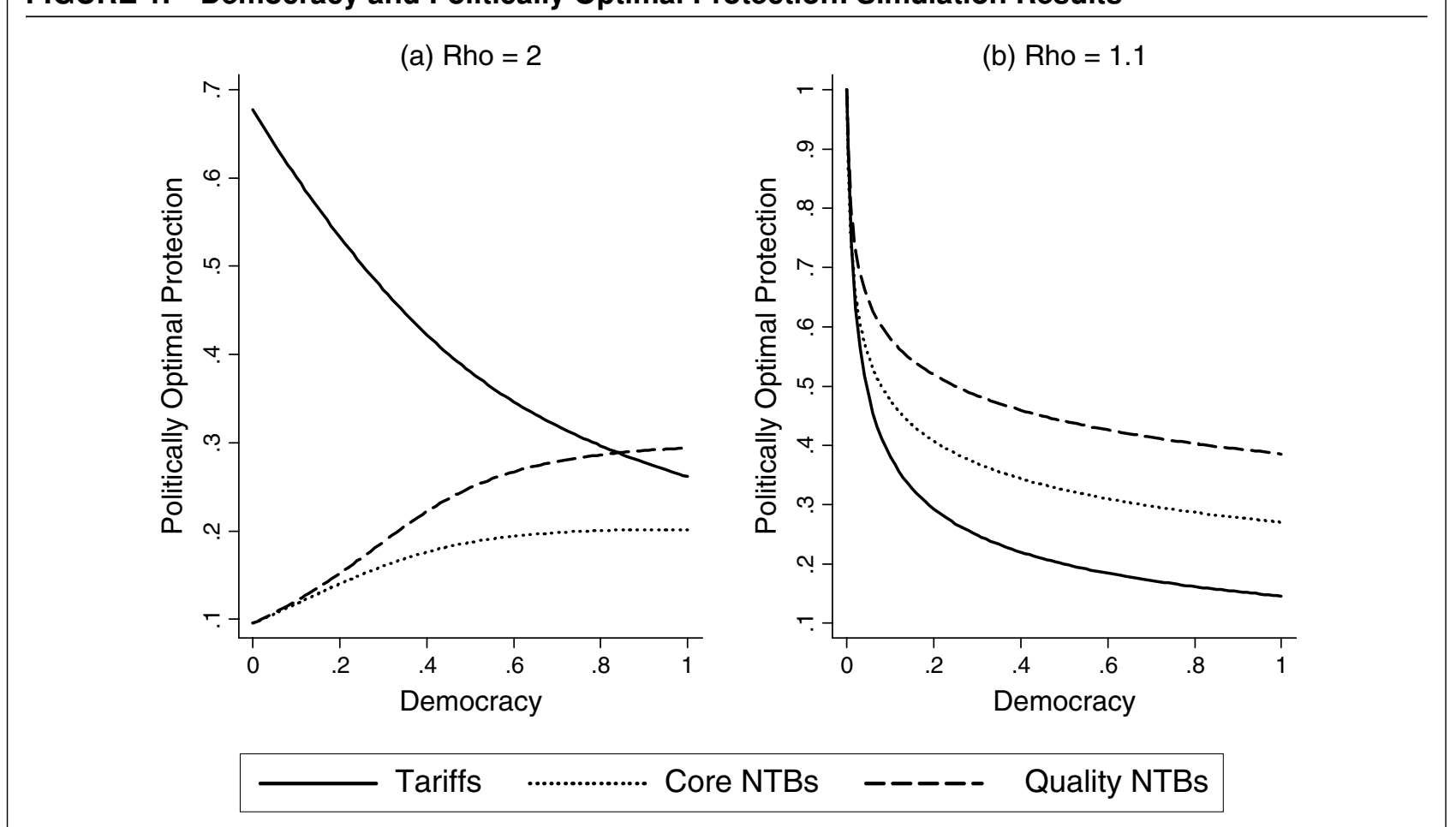

Figure 1(a) plots political support-maximizing levels of tariffs, core, and quality NTBs against the level of democracy for $\rho=2$. Figure 1(b) shows these same relationships for $\rho=1.1$. In Figure 1(a), as the solid line shows, increases in democracy lead to tariff reductions: as democracy rises from 0 to 1 , the politically optimal tariff falls from .68 to .26 . However, the dotted and dashed lines show that increases in democracy lead to higher core and quality NTBs, respectively: as democracy rises from 0 to 1 , core NTBs double from .1 to .2 , while quality NTBs triple from .1 to .3 . Increasing the level of democracy thus leads to tariff reductions, a rise in core NTBs, and an even larger rise in quality NTBs. This is the modal outcome, occurring in about $92 \%$ of my simulations. Moreover, the frequency of this outcome increases rapidly as $\rho$ rises above its minimum level of 1.1. The Figure 1(a)-type outcome occurs in $96 \%$ of cases when $\rho>1.5,98 \%$ of cases when $\rho>2$, and $99 \%$ of cases when $\rho>3$.

Variation in democracy has different effects when $\rho$ is extremely low, as Figure 1(b) makes clear. In this case, increases in democracy lead to liberalization of all three policy instruments. As democracy rises from 0 to 1 , tariffs, core NTBs, and quality NTBs fall from prohibitive levels to $.15, .27$, and .39 , respectively. Democracy has the same relative effects as before: it still leads to relatively high quality NTBs, lower core NTBs, and still lower tariffs. However, the absolute effects are different: increases in democracy now lead to absolute liberalization of all three forms of protection. The absolute effects of democracy thus depend critically on $\rho$, and hence on the elasticity of tariff revenues to tariff rates. Democracy leads to lower tariffs but higher NTBs when tariffs are effective at generating revenue, but it leads to across-the-board liberalization when tariffs are ineffective.

The intuition behind these results is straightforward. When tariff-revenue elasticities are high, governments have incentives to protect interest groups with tariffs, which generate revenue as well as interest-group contributions. Tariffs also reduce voter support, but this matters only to the extent that votes matter. Undemocratic governments thus employ tariffs heavily because the revenue gains outweigh the losses in voter support. They also keep NTB protection low, both because NTBs reduce tariff revenue and because high tariffs reduce the marginal contribution gains from NTBs. Democracy changes these incentives by increasing the relative importance of votes. As the degree of democracy rises, the electoral costs of tariffs increasingly outweigh the revenue gains. Democratic governments thus liberalize tariffs, which increases their popular support but reduces both tariff revenues and interestgroup contributions. They recoup some of these financial losses by employing NTBs, which satisfy interest groups at lower electoral cost. Democracy thus leads to lower tariffs, higher core NTBs, and even higher quality NTBs.

Democracy has different effects when tariff-revenue elasticities are extremely low. In this case, revenue considerations are virtually absent and governments focus almost entirely on interest-group contributions and voter support. As democracy approaches zero, voter support becomes irrelevant and governments become pure contribution maximizers. This leads them to employ nearly symmetric and prohibitive levels of all three 
forms of protection. ${ }^{6}$ Hence, when tariffs are ineffective at generating revenue, undemocratic governments have high levels of all trade barriers. Democracy leads to reductions in all trade barriers by increasing the political importance of voter support.

Because the impact of democracy on trade policy is, in theory, conditional on tariff-revenue elasticities, we cannot predict this impact without knowing how high these elasticities are in practice. Most studies of developing countries (International Monetary Fund 2005; Khattry and Rao 2002) indicate that tariff revenue elasticities are not only positive but also quite high. For example, Khattry and Rao (2002) find that a onepercentage point increase in the tariff rate leads to a .77 percentage point increase in tariff revenues as a percentage of GDP. Elasticities in developed countries are presumably even higher, because tariffs are lower and elasticities decline with the tariff rate. Because tariffs are, in practice, quite effective at generating revenue, regime type should have the asymmetric effects shown in Figure 1(a). Hence, more democratic countries should have lower tariffs, higher core NTBs, and still higher quality NTBs than less democratic ones.

Before testing this hypothesis, it is worth discussing one possible objection to my model. I assume that interest-group contributions and tariff revenues are fungible: both are sources of money that can be used to maintain power. This assumption is realistic for autocracies, where rulers often draw no distinction between public and private funds, but is less realistic for democracies, where politicians typically cannot use public funds for personal electoral gain. A more realistic model might thus multiply $R$ by $(1-D)$ to capture the fact that democracy reduces the political value of tariff revenues.

Although this change would make the model more realistic, it would not alter my conclusions. Recall that democracy affects different trade policies differently because democracies attach less weight than do autocracies to tariff revenues relative to voter support: this is why democratic leaders forgo revenues to capture votes, whereas autocratic leaders forgo votes to capture revenues. In my model, these different relative weights result from multiplying $V$ by $D$. If, in addition, I reduce the absolute importance of tariff revenues in democracies by multiplying $R$ by $(1-D)$, this only magnifies the current distinction between democracies and autocracies. My conclusions thus remain qualitatively the same, but democracy leads to even lower tariffs and higher NTBs. The fungibility assumption is thus not crucial, but it does ensure that democracies and autocracies are identical in all respects except for the weight attached to voter support. It thus allows us to isolate the trade policy consequences of variation in voter influence, which, more than anything else, differentiates democracies from autocracies.

\footnotetext{
${ }^{6}$ When democracy is zero, the optimal trade policy is indeterminate because contributions are maximized by a prohibitive tariff combined with any level of the other two instruments.
}

\section{DATA AND ANALYSIS}

I test my hypothesis by examining the impact of democracy on most-favored-nation (MFN) tariff rates and NTB coverage in 75 countries in the 1990s. All tradebarrier data are from the United Nations Commission on Trade and Development's Trade Analysis and Information System (TRAINS). ${ }^{7}$ My sample includes all cases for which data were available. It contains both developed and developing countries but is dominated by the latter, both because developing countries are more numerous and because my sample excludes countries that joined the European Union (EU) before 1990. TRAINS does not provide data for these countries because they share a common commercial policy. Data availability ranges from one to six years per country. A full list of countries and years is provided in the Appendix.

Although TRAINS provides multiple years for some countries, the data do not lend themselves to timeseries cross-section analysis. Over one-third of the countries have data for only one year, and the average number of years is only 3 for tariffs and 2 for NTBs. Moreover, the observations are unevenly spaced: in some cases, observations are separated by only one year, whereas in others they are separated by as many as seven. In addition, panels are highly unbalanced and longitudinal variation within countries is small compared with cross-national variation. For these reasons, I create a purely cross-sectional dataset by averaging values for all variables across available years.

\section{Dependent Variables}

I employ three dependent variables. Tariff Ti coun- $_{i}$ try $i$ 's mean statutory MFN tariff rate. Core $N T B_{i}$ is country $i$ 's core NTB coverage ratio, that is, the proportion of $i$ 's imports covered by core NTBs. Quality $N T B_{i}$ is country $i$ 's quality NTB coverage ratio. I employ coverage ratios because they are the best and most commonly employed NTB measure (Gawande and Hansen 1999; Mansfield and Busch 1995), although frequency ratios - the proportion of tariff lines covered by NTBs-produce similar results.

\section{Independent Variables}

I employ two democracy measures. Polity $y_{i}$ is the Polity IV Polity variable, a multidimensional measure of political competitiveness that ranges from -10 for full autocracies to +10 for full democracies. Electoral Competitiveness $s_{i}$ is the sum of the World Bank's Legislative and Executive Indices of Electoral Competitiveness, obtained from the World Bank's Database of Political Institutions. These indices measure the competitiveness of legislative and executive elections, respectively, and range from 1 when no elections are held

\footnotetext{
${ }^{7}$ Specifically, they come from Haveman's extracts from TRAINS versions $2-8$
} 
to 7 for elections in which the largest party received less than $75 \%$ of the vote. Electoral competitiveness thus ranges from 2 to 14 . The two measures are highly correlated $(r=.75)$, but the Polity scores capture more variation in the political competitiveness of nominally democratic countries: of the 48 sample countries that the World Bank codes as fully democratic, only 18 are full democracies according to Polity. Because I postulate a continuous relationship between democracy and trade policy, the more nuanced Polity measure is more appropriate for testing my hypothesis. I thus include the World Bank measure mainly as a robustness check. If my argument is correct, both variables will be negatively related to tariffs but positively related to NTBs.

\section{Control Variables}

Economic development may affect trade policy directly. Wealthier countries tend to have lower tariffs, in part because poor countries with weak state capacity rely heavily on tariffs as a source of revenue. Development might also affect quality NTB use if wealthier countries tend to have higher product standards. Because development and democracy are correlated, it is essential to control for the effects of the former when measuring the effects of the latter. I thus include $\ln ($ GDP per capita $i)$, the log of country $i$ 's real GDP per capita in 1995 dollars. ${ }^{8}$ Data on real GDP per capita and other economic controls are from the World Bank's World Development Indicators.

A country's economic size may also affect its trade policies (Mansfield and Busch 1995). Larger economies are less dependent on both imports and exports than smaller ones and may thus be more willing to employ protection. More prosaically, larger economies are also more diversified and have more domestic industries to protect. I thus include $\ln \left(G D P_{i}\right)$, the log of country $i$ 's real GDP in 1995 dollars, to control for the effects of economic size. I also include $\ln \left(\right.$ Export Dependence $\left._{i}\right)$, the $\log$ of country $i$ 's export-to-GDP ratio, because more export-dependent countries may be less willing to employ trade barriers that provoke retaliatory measures from trading partners (Gawande and Hansen 1999).

I include several standard macroeconomic controls. Country i's Real Effective Exchange Rate E $_{i}$ is included in case strong domestic currencies generate demands for protection (Mansfield and Busch 1995). Growth country $i$ 's GDP per capita growth rate, is included to control for business cycle effects (Cassing, McKeown, and Ochs 1986). ${ }^{9} \Delta$ Import Penetration, , the change in country $i$ 's imports-to-GDP ratio over the three years preceding dependent-variable observations, is included in case import surges increase protectionist demands (Trefler 1993).

\footnotetext{
${ }^{8}$ I log GDP per capita, GDP, export dependence, and government spending to reduce skewness.

${ }^{9}$ I employ growth rates rather than unemployment due to the greater availability of growth data. Including unemployment severely truncates the sample but does not greatly alter my results.
}

More open economies typically exhibit higher government spending (Adsera and Boix 2002). One possible explanation for this is that transfer programs facilitate liberalization by allowing the winners from trade to compensate the losers. I thus include $\ln$ (Government Spending $i$, the log of country $i$ 's government consumption spending as a percentage of GDP.

$G A T T_{i}$, a dummy for membership in the General Agreement on Tariffs and Trade, is included in case GATT membership affects trade policy. Theoretically, GATT members should have more liberal trade policies, although Rose (2004) finds little evidence of this, and Milner and Kubota (2005) find that GATT members actually have higher tariffs.

Finally, I include Tariff $i$, country $i$ 's average MFN tariff, in the NTB regressions because previous research shows that the decision to use NTBs is affected by prior tariff levels (Busch and Reinhardt 1999; Mansfield and Busch 1995). I do not include NTBs as a control in the tariff regressions because theory and empirical evidence suggest that tariffs are exogenous to NTBs. Because tariffs are bound by GATT rules, governments are more likely to treat prior tariff levels as constraints. Empirically, studies show that causality runs from tariffs to NTBs and not vice-versa (Ray 1981). I thus treat tariffs as exogenous, although my tariff results are robust to the inclusion of NTBs on the right-hand side.

\section{Results}

I estimate the impact of the aforementioned variables on trade policy using ordinary least-squares (OLS) regression with White-corrected standard errors. Results are shown in Table 1.

Controls are generally signed as expected. Wealthier countries have significantly lower tariffs, while larger economies have significantly higher tariffs and quality NTBs. Export dependence is negatively signed and significant for core NTBs. $\Delta$ import penetration is, surprisingly, negatively signed, but is only marginally significant in one model. Like Milner and Kubota (2005), I find that GATT membership is associated with higher tariffs, but it is negatively related to NTBs. As in most previous studies (Busch and Reinhardt 1999; Lee and Swagel 1997), the tariff control is positively signed.

Democracy has the predicted effects on trade policy. Both democracy measures are negatively signed and significant in the tariff regressions, indicating that more democratic countries have lower tariffs than less democratic ones. Both measures are positively signed for core NTBs-indicating that democracies have higher core NTBs-although only the Polity measure is significant. Finally, both measures are positive and significant in the quality NTB regressions, indicating that more democratic countries have higher quality NTBs. The results in Table 1 thus provide strong support for my hypothesis. They indicate, first, that democracy leads to lower tariffs but higher NTBs. They also show that democracy has larger effects on 


\begin{tabular}{|c|c|c|c|c|c|c|}
\hline \multirow{3}{*}{$\begin{array}{l}\text { Explanatory Variable } \\
\text { Polity }_{i}\end{array}$} & \multicolumn{6}{|c|}{ Dependent Variable } \\
\hline & \multicolumn{2}{|c|}{ Tariff $_{i}$} & \multicolumn{2}{|c|}{ Core NTB ${ }_{i}$} & \multicolumn{2}{|c|}{ Quality NTB ${ }_{i}$} \\
\hline & $\begin{array}{l}-.391^{* *} \\
(.163)\end{array}$ & & $\begin{array}{l}.368^{* *} \\
(.164)\end{array}$ & & $\begin{array}{l}.701^{* * *} \\
(.257)\end{array}$ & \\
\hline Electoral Competition $_{i}$ & & $\begin{array}{l}-.731^{* *} \\
(.295)\end{array}$ & & $\begin{array}{c}.237 \\
(.245)\end{array}$ & & $\begin{array}{l}1.20^{* *} \\
(.559)\end{array}$ \\
\hline In(GDP per capita $\left.{ }_{i}\right)$ & $\begin{array}{c}-4.19^{* * *} \\
(1.04)\end{array}$ & $\begin{array}{c}-4.51^{* * *} \\
(.963)\end{array}$ & $\begin{array}{c}2.52 \\
(1.61)\end{array}$ & $\begin{array}{c}3.06^{*} \\
(1.73)\end{array}$ & $\begin{array}{l}-.216 \\
(2.02)\end{array}$ & $\begin{array}{c}.500 \\
(2.01)\end{array}$ \\
\hline $\ln \left(\mathrm{GDP}_{i}\right)$ & $\begin{array}{r}1.60^{* *} \\
(.696)\end{array}$ & $\begin{array}{c}1.69^{* *} \\
(.687)\end{array}$ & $\begin{array}{c}.815 \\
(.695)\end{array}$ & $\begin{array}{c}.682 \\
(.712)\end{array}$ & $\begin{array}{l}2.75^{* *} \\
(1.34)\end{array}$ & $\begin{array}{l}2.49^{*} \\
(1.40)\end{array}$ \\
\hline In(Export Dependence $\left.{ }_{i}\right)$ & $\begin{array}{r}.140 \\
(2.02)\end{array}$ & $\begin{array}{r}.445 \\
(1.91)\end{array}$ & $\begin{array}{l}-2.87^{*} \\
(1.53)\end{array}$ & $\begin{array}{c}-3.49^{* *} \\
(1.50)\end{array}$ & $\begin{array}{c}-3.26 \\
(3.31)\end{array}$ & $\begin{array}{c}-4.87 \\
(3.28)\end{array}$ \\
\hline Real Exchange Rate ${ }_{i}$ & $\begin{array}{c}-.047 \\
(.079)\end{array}$ & $\begin{array}{c}-.048 \\
(.076)\end{array}$ & $\begin{array}{c}-.081 \\
(.075)\end{array}$ & $\begin{array}{c}-.058 \\
(.074)\end{array}$ & $\begin{array}{c}-.035 \\
(.136)\end{array}$ & $\begin{array}{r}-.019 \\
(.139)\end{array}$ \\
\hline Growth $_{i}$ & $\begin{array}{l}.154 \\
(.275)\end{array}$ & $\begin{array}{l}.189 \\
(.282)\end{array}$ & $\begin{array}{l}.177 \\
(.258)\end{array}$ & $\begin{array}{l}.118 \\
(.252)\end{array}$ & $\begin{array}{l}.166 \\
(.440)\end{array}$ & $\begin{array}{l}.203 \\
. .470)\end{array}$ \\
\hline$\Delta$ Import Penetration $_{i}$ & $\begin{array}{l}.065 \\
(.197)\end{array}$ & $\begin{array}{l}.098 \\
(.196)\end{array}$ & $\begin{array}{c}-.052 \\
(.106)\end{array}$ & $\begin{array}{c}-.019 \\
(.094)\end{array}$ & $\begin{array}{r}-.277^{*} \\
(.154)\end{array}$ & $\begin{array}{r}-.206 \\
(.169)\end{array}$ \\
\hline In(Government Spending $i$ ) & $\begin{array}{c}-1.49 \\
(4.16)\end{array}$ & $\begin{array}{c}-2.13 \\
(4.30)\end{array}$ & $\begin{array}{c}.995 \\
(2.01)\end{array}$ & $\begin{array}{c}.454 \\
(2.02)\end{array}$ & $\begin{array}{l}2.60 \\
(5.47)\end{array}$ & $\begin{array}{l}2.87 \\
(5.42)\end{array}$ \\
\hline GATT $_{i}$ & $\begin{array}{l}5.93^{* *} \\
(2.23)\end{array}$ & $\begin{array}{l}5.47^{* *} \\
(2.39)\end{array}$ & $\begin{array}{l}-1.38 \\
(1.81)\end{array}$ & $\begin{array}{l}-.094 \\
(1.69)\end{array}$ & $\begin{array}{c}-9.12^{* *} \\
(4.45)\end{array}$ & $\begin{array}{r}-8.29^{*} \\
(4.60)\end{array}$ \\
\hline Tariff $_{i}$ & & & $\begin{array}{l}.435^{* * *} \\
(.160)\end{array}$ & $\begin{array}{l}.387^{* *} \\
(.156)\end{array}$ & $\begin{array}{c}.501^{* *} \\
(.234)\end{array}$ & $\begin{array}{r}.420^{*} \\
(.221)\end{array}$ \\
\hline Constant & $\begin{array}{c}11.4 \\
(22.1)\end{array}$ & $\begin{array}{c}20.2 \\
(22.4)\end{array}$ & $\begin{array}{l}-24.6^{*} \\
(13.8)\end{array}$ & $\begin{array}{l}-26.0^{*} \\
(14.4)\end{array}$ & $\begin{array}{c}-41.2 \\
(37.1)\end{array}$ & $\begin{array}{l}-49.2 \\
(38.5)\end{array}$ \\
\hline $\begin{array}{l}\text { Observations } \\
R^{2} \\
p>F\end{array}$ & $\begin{array}{c}74 \\
.48 \\
0.0000 \\
\end{array}$ & $\begin{array}{c}75 \\
.48 \\
0.0000\end{array}$ & $\begin{array}{c}74 \\
.33 \\
0.0000\end{array}$ & $\begin{array}{c}75 \\
.31 \\
0.0005\end{array}$ & $\begin{array}{c}72 \\
.33 \\
0.0016\end{array}$ & $\begin{array}{c}73 \\
.30 \\
0.0151\end{array}$ \\
\hline
\end{tabular}

quality than on core NTBs: the democracy coefficients are both larger and more robust in the quality than in the core NTB regressions. ${ }^{10}$

Figure 2 presents the substantive effects of democracy on trade policy by plotting predicted values of tariffs, core, and quality NTBs against Polity scores, with all other variables held constant at their means. As the solid line shows, going from -10 to 10 on the polity scale causes the predicted MFN tariff to fall by 7.8 percentage points, from $19 \%$ to $11.2 \%$. The dotted line shows that the same increase in democracy causes predicted core NTB coverage to rise by 7.4 percentage points, from $.8 \%$ to $8.2 \%$. Finally, the dashed line shows that this increase in democracy causes predicted quality NTB coverage to rise by 14 percentage points, from $8.4 \%$ to $22.4 \%$.

Although these minimum-to-maximum comparisons illustrate the potential impact of democracy on trade policy, its practical impact is smaller because variation in democracy is in practice less extreme. It is thus useful to consider the trade policy consequences of a one-standard deviation change in the polity score. The standard deviation in my sample is 6.2 ; hence a one-standard deviation change in the

\footnotetext{
${ }^{10}$ This remains true if the dependent variables are measured as positive and negative standard deviations from their respective means.
}

polity score lowers tariffs by $6.2 \times .391=2.4$ percentage points. The same change in the polity score produces a $6.2 \times .368=2.3$ percentage point increase in core NTBs and a $6.2 \times .701=4.3$ percentage point increase in quality NTBs. These effects are not trivial, but neither do they indicate that regime type alone explains why some economies are open while others are closed. Democracy's impact on trade policy, although potentially quite large, is thus modest in practice.

Some readers may be concerned that the omission of EU countries biases my results. Because TRAINS does not provide data on individual EU members, I cannot conclusively dismiss this concern. However, TRAINS data on the EU as a unit does permit some informed speculation about how the inclusion of EU members would affect my results. Relative to my sample, the EU has very low tariffs, very high core NTB coverage, and moderate quality NTB coverage. The inclusion of EU members, all of which are democracies, should thus strengthen my tariff and core NTB results but weaken my quality NTB results. I "test" this hypothesis by simulating the inclusion of the 12 excluded EU members, assigning each its national values for all independent variables but aggregate EU values for trade policy. ${ }^{11}$ This sample change leads,

\footnotetext{
11 Although these countries would have different trade policies in the absence of the EU, this procedure reasonably simulates the
} 


\section{FIGURE 2. Democracy and Predicted Value of Tariffs and NTBs}

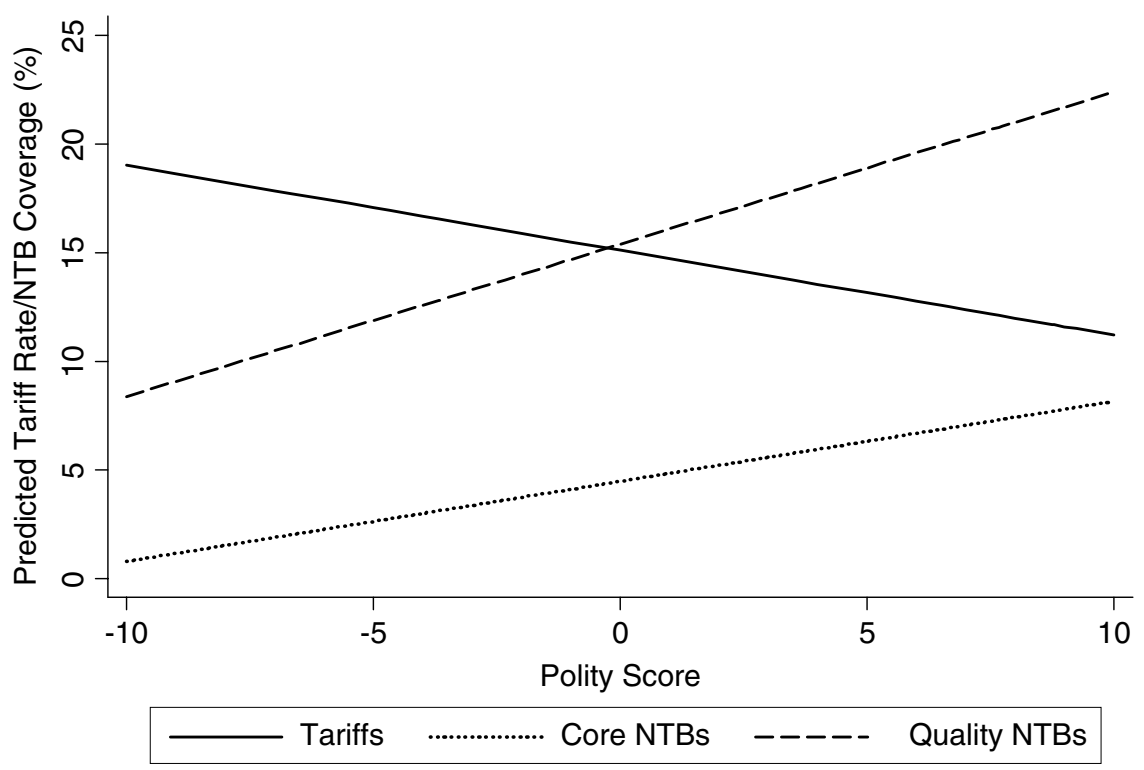

as expected, to larger coefficients for tariffs and core NTBs but smaller ones for quality NTBs. The magnitude of these changes is tiny, however, and does not alter either the significance or the ordinal ranking of the coefficients. Available evidence thus indicates that the inclusion of EU members would not notably alter my results.

Diagnostics indicate no multicollinearity problems: average variance inflation factors (VIFs) for the above models range from 1.85 to 1.90 , while VIFs for individual regressors range from 1.14 to 4.29 . Only GDP and GDP per capita have average VIFs above 2.0, and my results are robust to the removal of these and all insignificant controls. They are also robust to the exclusion of all individual countries and to "robust regression" estimators that downweight influential cases. My results thus hold up well to various model specifications and estimation techniques.

Although the previous analysis shows that democracy has the predicted effects on trade policies, it does not tell us why. This question is important, however, because democracy could affect trade policy in various ways. It might, for example, promote tariff liberalization via its effects on international cooperation rather than through a domestic electoral channel. Likewise, democracy might increase quality NTB use, not because it encourages obfuscation, but because it makes governments more responsive to voter concerns about public health, safety, and the environment. We thus need additional tests to identify the causal mechanisms linking democracy to trade policy.

non-EU counterfactual if the EU policy is an average of member policy preferences.

\section{DEMOCRACY MATTERS, BUT WHY?}

\section{Why Do Democracies Have Lower Tariffs?}

I argue that democracies have lower tariffs because democracy allows challenges to the government's tariffs and thus creates pressures to reduce the latter. This argument implies that high tariffs in democracies should elicit strong criticism. Is this true? ${ }^{12}$

I investigate this question using data on party election programs from the Comparative Manifesto Project (CMP), obtained from Budge et al. (2001). The CMP analyzes party election programs in 25 full democracies from 1945 to 1998 to determine party stances on a wide range of issues, including trade policy. The CMP first codes program statements on a given issue as either positive or negative, then-to control for the length of party platforms-expresses the number of statements in each issue area as a percentage of total statements in the program. The resulting frequencies indicate both the nature and intensity of party positions in each issue area. For example, a large number of statements condemning protectionism would indicate strong electoral opposition to the latter, whereas a smaller number of such condemnations would indicate weaker opposition. Election programs are ideal for measuring campaign stances on trade policy because, as Budge et al. (5) note, they are prominent, authoritative campaign statements: "Even when not widely read they

\footnotetext{
12 Strictly speaking, I do not predict such challenges because governments rationally anticipate challenges and, in equilibrium, eschew trade barriers that would be challenged, so no political conflict over trade policy ever occurs. The following tests are thus motivated by the empirical reality that political conflict over trade policy sometimes occurs.
} 


\begin{tabular}{|c|c|c|c|c|c|}
\hline & $\begin{array}{c}(1) \\
\text { FGLS }\end{array}$ & $\begin{array}{l}\text { (2) } \\
\text { LDV }\end{array}$ & $\begin{array}{c}\text { (3) } \\
\text { Year FE }\end{array}$ & $\begin{array}{c}(4) \\
\text { Non-EU }\end{array}$ & $\begin{array}{c}(5) \\
1990 \mathrm{~s}\end{array}$ \\
\hline$\overline{\text { Challenges }}_{i t-1}$ & & $\begin{array}{l}.421^{* *} \\
(.190)\end{array}$ & $\begin{array}{l}.398^{* * *} \\
(.087)\end{array}$ & $\begin{array}{l}.401^{*} \\
(.214)\end{array}$ & $\begin{array}{l}.699^{* * *} \\
(.082)\end{array}$ \\
\hline Tariff $_{i t-1}$ & $\begin{array}{l}.068^{* * *} \\
(.020)\end{array}$ & $\begin{array}{l}.071^{* *} \\
(.026)\end{array}$ & $\begin{array}{l}.084^{* * *} \\
(.029)\end{array}$ & $\begin{array}{l}.090^{* *} \\
(.036)\end{array}$ & $\begin{array}{l}.071^{*} \\
(.038)\end{array}$ \\
\hline Constant & $\begin{array}{l}.415^{* * * *} \\
(.079)\end{array}$ & $\begin{array}{l}.337^{* *} \\
(.136)\end{array}$ & $\begin{array}{c}.974 \\
(1.49)\end{array}$ & $\begin{array}{l}.450 \\
(.285)\end{array}$ & $\begin{array}{l}.049 \\
(.099)\end{array}$ \\
\hline $\begin{array}{l}\text { Observations } \\
\mathrm{R}^{2}\end{array}$ & 153 & $\begin{array}{l}153 \\
.22\end{array}$ & $\begin{array}{l}153 \\
.33\end{array}$ & $\begin{array}{l}77 \\
.20\end{array}$ & $\begin{array}{l}58 \\
.71\end{array}$ \\
\hline$p>F$ & $0.0007^{a}$ & 0.0008 & 0.0021 & 0.0043 & 0.0000 \\
\hline
\end{tabular}

[are] adapted and launched with great publicity and picked up by the media."

To determine whether high tariffs lead to electoral challenges, I regress Challenges it $_{\text {- }}$ a measure of challenges to protectionist policies in country $i$ in election year $t$-against Tariff $f_{i t-1}$, country $i$ 's average tariff rate one year prior to $t .{ }^{13}$ The analysis is thus time-series cross-sectional (TSCS) with the country-election year as the unit of analysis. To measure challenges, I first obtain the frequency of condemnations of "extension or maintenance of tariffs to protect internal markets [and] other domestic economic protectionism such as quota restrictions" (Budge et al. 2001, 224-25) for each party election program. I then average these frequencies by country-election year to estimate national electoral criticism of protectionist policies. To reduce the influence of marginal parties, I include only the four largest parties (by vote share) per country. Because TRAINS provides tariff data for only a few years, I employ the World Development Indicators import duties measure-which is available for most years from approximately 1970 onwards - for this analysis. If high tariffs increase the frequency of electoral challenges to the government's trade policies, tariffs will be positively signed.

There is some debate about the merits of lagged dependent variables (LDVs) in TSCS analysis (Keele and Kelly 2006). I thus estimate two model specifications: one without an LDV using feasible generalized least squares (FGLS) with corrections for an AR(1) time series process and panel heteroskedasticity and another with an LDV and "robust cluster" standard errors that correct for within-country correlation of residuals. Results are shown in Table 2.

Column 1, which presents the FGLS regression, indicates that tariffs have a significant positive effect on electoral challenges to protection. In column 2 , the LDV model yields similar results. Because the LDV model is conservative-creating bias, if at all, against

\footnotetext{
${ }^{13} \mathrm{I}$ lag tariffs one year because it takes time to draft election programs.
}

significance-I employ LDVs in the remaining regressions. In column 3, I control for year fixed effects because Milner and Judkins (2004) find that parties have become more liberal over time, and I again obtain similar results. In column 4, I restrict the sample to non-EU countries because the electoral politics of trade may differ within and outside the EU. Because EU governments cannot conduct independent trade policies, the link between tariffs and electoral challenges should be weaker in EU countries. The removal of these countries should thus cause the tariff coefficient to grow. Column 4 shows exactly this. Finally, because my trade policy analysis is limited to the 1990s, column 5 restricts the sample to elections held in this period. Although the tariff coefficient declines slightly in significance, its magnitude is identical to that of the full sample (column 2). All five models thus tell the same story: higher tariffs lead to stronger criticism of trade barriers in electoral campaigns.

These results almost certainly do not reflect an endogenous relationship between electoral challenges and tariffs: theoretically, the former should not cause the latter to rise. Rather, these results indicate that democratic elections lead to criticism of high tariffs and thus support my causal explanation linking democracy to low tariffs.

Although I have shown that high tariffs elicit electoral criticism of trade barriers, I have not shown that high NTBs do not. Unfortunately, the dearth of longitudinal NTB data prevents me from simply repeating the above analysis with NTBs on the right-hand side. I thus exploit the cross-sectional TRAINS data, regressing electoral challenges against all three trade policy measures for available countries and years. If my theory is correct, higher tariffs should lead to more electoral challenges but higher NTBs should not. My analysis supports this hypothesis: tariffs are again significant and positive, but both NTB measures are insignificant. ${ }^{14}$ Because the samples for these regressions

\footnotetext{
14 The tariff coefficient is .245, with a p-value of .004; the core NTB coefficient is -.022 , with a p-value of .171 ; and the quality NTB coefficient is .002 , with a p-value of .883 .
} 
are very small (21 for tariffs and 17 for NTBs), these results are suggestive rather than conclusive. However, they support my claim that tariffs are electorally more costly than NTBs.

\section{Why Do Democracies Have Higher Quality NTBs?}

Democracy could promote quality NTB use in two ways: first, by promoting obfuscation, and second, by making politicians more responsive to public concerns about health, safety, and the environment. I test these competing hypotheses in two ways.

First, I include proxies for public demand for health, safety, and environmental standards in the quality NTB regressions. If public demand for high standards leads governments to employ quality NTBs, then the former should be positively related to the latter. Although one could, in principle, measure such demand directly through public-opinion surveys, such data are unavailable for most countries in my study. I thus employ three proxies.

The first, ISO Certifications , $_{i}$, is the number of companies per 1,000 population in country $i$ that receive International Organization for Standardization (ISO) 9,000 certification. ${ }^{15}$ To be certified, companies must be audited by external bodies to verify that they meet the requirements of ISO 9000, the most widely used generic "quality management" standard. ${ }^{16}$ A high number of certifications per capita indicates widespread conformity to high standards. The second, Environmental Regulation $_{i}$, is a multidimensional measure of environmental governance provided by the World Economic Forum, the Yale Center for Environmental Law and Policy, and the Center for International Earth Science Information Network at Columbia University (2002). ${ }^{17}$ Higher values indicate more stringent environmental regulation. The third measure, Water Quality $_{i}$, is a multidimensional index of water quality obtained from the same source as the previous variable. Higher values indicate higher water quality.

Because these proxies are diverse, we need to ask what each proxies. ISO certification most clearly proxies consumer demand for product quality: firms would not seek certification in the absence of consumer demand. The latter could, however, influence the former through either government regulation or market forces: consumers could pressure their governments to regulate domestic firms, which consequently meet ISO standards, or consumers could influence firms through

\footnotetext{
15 ISO data are from The ISO Survey of ISO 9000 and ISO 14000 Certificates, available at http://www.iso.org/iso/en/iso900014000/pdf/survey10thcycle.pdf.

16 The ISO (http://www.iso.org/iso/en/iso9000-14000/understand/ basics/general/basics_4.html) defines "quality management" as "what the organization does to ensure that its products or services satisfy the customer's quality requirements and comply with any regulations applicable to those products or services."

17 For more information, see http://www.ciesin.columbia.edu/indicators/ESI/.
}

the marketplace, with similar results. For our purposes, it does not matter which explanation is correct: in either case, a nonrelationship between ISO certifications and quality NTBs would indicate that the latter are not motivated by the consumer concerns that led-either through the market or the state-to the former.

Environmental regulation and water quality more clearly proxy government regulation. Their inclusion makes sense given two assumptions. First, stringent domestic environmental standards reflect public rather than interest-group pressures because domestic industries have little to gain from such measures. ${ }^{18}$ Second, publics that demand clean air and water are generally conscious of health and safety and are thus likely to demand higher product standards as well. If these assumptions are correct, and if quality NTBs reflect public pressures, then these two proxies will be positively related to quality NTBs.

Bivariate correlations between these proxies and quality NTBs are close to zero: .02 for ISO certifications, -.01 for environmental regulation, and .04 for water quality. To ensure that the partial correlations are not higher, I include these measures in the quality NTB regressions. Results are shown in Table 3.

Table 3 shows results for the Polity measure (columns 1-3) and the electoral competition index (columns 4-6) as proxies for consumer pressures are included one at a time. Inclusion of these proxies does not affect the democracy results, nor do the proxies themselves approach statistical significance. Moreover, all three proxies are negatively signed, indicating that countries with more ISO certifications, stricter environmental standards, and higher water quality actually have lower quality NTBs. Because these proxies do not directly measure voter views on product regulation, I cannot reject the possibility that voter pressures lead to quality NTBs. I have, however, found no evidence that they do.

To test more directly the hypothesis that quality NTBs in democracies reflect interest-group pressures, I analyze the determinants of sectoral NTBs in 43 countries classified by the World Bank as fully competitive democracies. ${ }^{19}$ Specifically, I compare the impact of sectoral interest-group variables on core NTBs-which are clearly protectionist-with their impact on quality NTBs. If these variables have similar effects on core and quality NTBs, we can infer that the latter, like the former, reflect protectionist pressures. Conversely, if interest-group pressures are not related to quality NTBs, then the latter may serve more public-spirited goals.

\footnotetext{
18 In contrast to international standards, which might be used to limit imports.

19 As before, my analysis excludes the EU-12. However, as a robustness check I have performed the sectoral analysis with these countries, assigning each the trade policies of the EU as a whole. As before, the inclusion of EU members has no noteworthy impact on my results.
} 


\begin{tabular}{|c|c|c|c|c|c|c|}
\hline Explanatory Variable & & $\mathrm{De}$ & ndent Variab & Quality NTB & & \\
\hline Polity $_{i}$ & $\begin{array}{l}.738^{* * *} \\
(.267)\end{array}$ & $\begin{array}{l}.840^{* * * *} \\
(.301)\end{array}$ & $\begin{array}{l}.812^{* *} \\
(.317)\end{array}$ & & & \\
\hline Electoral Competition $_{i}$ & & & & $\begin{array}{l}1.22^{* *} \\
(.599)\end{array}$ & $\begin{array}{l}1.34^{* *} \\
(.614)\end{array}$ & $\begin{array}{l}1.29^{* *} \\
(.645)\end{array}$ \\
\hline ISO Certifications $_{i}$ & $\begin{array}{c}-3.56 \\
(5.71)\end{array}$ & & & $\begin{array}{c}-2.27 \\
(5.98)\end{array}$ & & \\
\hline Environmental Regulation $_{i}$ & & $\begin{array}{c}-5.50 \\
(3.63)\end{array}$ & & & $\begin{array}{c}-4.18 \\
(3.53)\end{array}$ & \\
\hline Water Quality $_{i}$ & & & $\begin{array}{c}-2.67 \\
(3.60)\end{array}$ & & & $\begin{array}{c}-1.03 \\
(3.26)\end{array}$ \\
\hline In(GDP per capita $\left.{ }_{i}\right)$ & $\begin{array}{r}.061 \\
(2.29)\end{array}$ & $\begin{array}{r}.487 \\
(2.37)\end{array}$ & $\begin{array}{l}-.040 \\
(2.09)\end{array}$ & $\begin{array}{r}.734 \\
(2.29)\end{array}$ & $\begin{array}{r}.885 \\
(2.40)\end{array}$ & $\begin{array}{r}.257 \\
(2.10)\end{array}$ \\
\hline $\ln \left(\mathrm{GDP}_{i}\right)$ & $\begin{array}{l}2.61^{*} \\
(1.54)\end{array}$ & $\begin{array}{c}2.60^{*} \\
(1.47)\end{array}$ & $\begin{array}{c}2.78^{*} \\
(1.41)\end{array}$ & $\begin{array}{c}2.28 \\
(1.60)\end{array}$ & $\begin{array}{c}2.50 \\
(1.56)\end{array}$ & $\begin{array}{c}2.68^{*} \\
(1.48)\end{array}$ \\
\hline In(Export Dependence $)$ & $\begin{array}{r}-3.22 \\
(3.43)\end{array}$ & $\begin{array}{c}-5.81 \\
(3.98)\end{array}$ & $\begin{array}{c}-4.56 \\
(3.99)\end{array}$ & $\begin{array}{r}-5.18 \\
(3.46)\end{array}$ & $\begin{array}{r}-7.18^{*} \\
(4.18)\end{array}$ & $\begin{array}{c}-5.91 \\
(4.25)\end{array}$ \\
\hline Real Exchange Rate $_{i}$ & $\begin{array}{c}-.070 \\
(.145)\end{array}$ & $\begin{array}{c}-.064 \\
(.150)\end{array}$ & $\begin{array}{c}-.050 \\
(.153)\end{array}$ & $\begin{array}{r}-.050 \\
(.150)\end{array}$ & $\begin{array}{r}-.036 \\
(.152)\end{array}$ & $\begin{array}{r}-.018 \\
(.150)\end{array}$ \\
\hline Growth $_{i}$ & $\begin{array}{l}.224 \\
(.461)\end{array}$ & $\begin{array}{l}.417 \\
(.524)\end{array}$ & $\begin{array}{l}.129 \\
(.462)\end{array}$ & $\begin{array}{l}.273 \\
(.489)\end{array}$ & $\begin{array}{l}.392 \\
(.547)\end{array}$ & $\begin{array}{l}.176 \\
(.484)\end{array}$ \\
\hline$\Delta$ Import Penetration $_{i}$ & $\begin{array}{r}-.316^{*} \\
(.162)\end{array}$ & $\begin{array}{r}-.230 \\
(.175)\end{array}$ & $\begin{array}{c}-.239 \\
(.181)\end{array}$ & $\begin{array}{r}-.230 \\
(.180)\end{array}$ & $\begin{array}{r}-.152 \\
(.200)\end{array}$ & $\begin{array}{r}-.164 \\
(.199)\end{array}$ \\
\hline In(Government Spending $)$ & $\begin{array}{l}2.58 \\
(5.48)\end{array}$ & $\begin{array}{l}6.26 \\
(6.14)\end{array}$ & $\begin{array}{c}4.43 \\
(6.12)\end{array}$ & $\begin{array}{c}2.93 \\
(5.50)\end{array}$ & $\begin{array}{l}5.77 \\
(6.06)\end{array}$ & $\begin{array}{c}4.10 \\
(6.17)\end{array}$ \\
\hline GATT $_{i}$ & $\begin{array}{r}-8.75^{*} \\
(4.80)\end{array}$ & $\begin{array}{r}-8.40^{*} \\
(4.51)\end{array}$ & $\begin{array}{c}-9.74^{* *} \\
(4.54)\end{array}$ & $\begin{array}{c}-8.34 \\
(5.06)\end{array}$ & $\begin{array}{r}-7.74^{*} \\
(4.62)\end{array}$ & $\begin{array}{r}-8.58^{*} \\
(4.68)\end{array}$ \\
\hline Tariff $_{i}$ & $\begin{array}{l}.493^{* *} \\
(.243)\end{array}$ & $\begin{array}{r}.450^{*} \\
(.263)\end{array}$ & $\begin{array}{r}.484^{*} \\
(.265)\end{array}$ & $\begin{array}{r}.421^{*} \\
(235)\end{array}$ & $\begin{array}{c}.340 \\
(.239)\end{array}$ & $\begin{array}{c}.373 \\
(.246)\end{array}$ \\
\hline Constant & $\begin{array}{c}-36.7 \\
(42.9)\end{array}$ & $\begin{array}{c}-42.2 \\
(38.3)\end{array}$ & $\begin{array}{c}-41.8 \\
(37.7)\end{array}$ & $\begin{array}{c}-41.8 \\
(44.9)\end{array}$ & $\begin{array}{c}-52.1 \\
(40.1)\end{array}$ & $\begin{array}{l}-52.2 \\
(39.8)\end{array}$ \\
\hline $\begin{array}{l}\text { Observations } \\
R^{2} \\
p>F\end{array}$ & $\begin{array}{c}70 \\
.32 \\
0.0053\end{array}$ & $\begin{array}{c}70 \\
.35 \\
0.0014\end{array}$ & $\begin{array}{c}70 \\
.33 \\
0.0025\end{array}$ & $\begin{array}{c}70 \\
.29 \\
0.0488\end{array}$ & $\begin{array}{c}71 \\
.32 \\
0.0143\end{array}$ & $\begin{array}{c}71 \\
.31 \\
0.0226\end{array}$ \\
\hline
\end{tabular}

As before, I perform a cross-sectional analysis that employs period averages for all variables. The dependent variable is Core (Quality) $N T B_{i j}$, the average of country $i$ 's NTB coverage in sector $j$ for available years. Sectors are defined at the 3-digit International Standard Industrial Classification (ISIC) level due to output and employment data constraints. Because sectoral observations within countries are not independent, I employ robust cluster estimates that correct for withincountry correlation of residuals.

I include four interest-group variables that previous research has shown to affect NTBs. Employment Share $_{i j}$, industry $j$ 's share of country $i$ 's total manufacturing employment, is included because larger sectors tend to be politically more influential and hence more protected (Busch and Reinhardt 1999; Lee and Swagel 1997). ${ }^{20}$ Import Penetration $i j$, the ratio of imports to domestic output in sector $j$ in country $i$, is included because sectors threatened by imports tend to demand, and to receive, more protection (Busch and Rein-

\footnotetext{
${ }^{20}$ Sectoral employment and output data are from UNIDO's Indus-
} trial Statistics Database. Sectoral trade data are from Feenstra 2000. hardt; Lee and Swagel). I include Export Dependence $i j$, the ratio of sector $j$ 's exports to output, because export-dependent sectors often seek domestic trade liberalization in exchange for foreign market access (Gilligan 1997; Gawande and Hansen 1999). Finally, I include $\Delta$ Import Penetration $_{i j}$ - the average change in industry import penetration over the three years preceding each NTB observation-to capture the effects of both import surges and industry decline, both of which should lead to greater demands for protection (Lee and Swagel 1997; Trefler 1993).

I also include a proxy for consumer demand for product quality in the quality NTB regression: $I S O$ Certifications $_{j}$, the total (i.e., global) number of ISO 9000-certified companies per billion dollars of global output in sector $j$. High values indicate that, globally, consumers demand high product quality in sector $j$. This proxy requires the strong assumption that crosssectoral variation in consumer concern is constant across countries: that is, that consumers in all countries care more about the quality of, say, pharmaceuticals than handbags. Although this assumption is questionable, it is also unavoidable because sector-specific data are unavailable for most countries. A significant 


\begin{tabular}{|c|c|c|}
\hline \multirow[b]{2}{*}{ Explanatory Variable } & \multicolumn{2}{|c|}{ Dependent Variable } \\
\hline & Core $\mathrm{NTB}_{i j}$ & Quality NTB $_{i j}$ \\
\hline In(Employment Share $\left.{ }_{i j}\right)$ & $\begin{array}{l}.508^{* * *} \\
(.101)\end{array}$ & $\begin{array}{l}.445^{* * *} \\
(.102)\end{array}$ \\
\hline In(Import Penetration $\left.{ }_{i j}\right)$ & $\begin{array}{l}.182^{* *} \\
(.081)\end{array}$ & $\begin{array}{l}.220^{* * *} \\
(.083)\end{array}$ \\
\hline In(Export Dependence $\left.{ }_{i j}\right)$ & $\begin{array}{r}-.220^{*} \\
(.119)\end{array}$ & $\begin{array}{l}-.260^{* * * *} \\
(.092)\end{array}$ \\
\hline$\Delta \ln \left(\right.$ Import Penetration $\left._{i j}\right)$ & $\begin{array}{l}-.179 \\
(.243)\end{array}$ & $\begin{array}{r}-.215 \\
(.151)\end{array}$ \\
\hline ISO Certifications $_{j}$ & & $\begin{array}{r}-.001 \\
(.002)\end{array}$ \\
\hline In(GDP per capita $)$ & $\begin{array}{l}.794^{* * *} \\
(.216)\end{array}$ & $\begin{array}{l}.233 \\
(.249)\end{array}$ \\
\hline $\ln \left(G_{D P}\right)$ & $\begin{array}{l}.247^{* *} \\
(.108)\end{array}$ & $\begin{array}{l}.340^{* *} \\
(.168)\end{array}$ \\
\hline Real Exchange Rate ${ }_{i}$ & $\begin{array}{c}-.031 \\
(.019)\end{array}$ & $\begin{array}{c}-.027 \\
(.017)\end{array}$ \\
\hline Growth $_{i}$ & $\begin{array}{c}-.048 \\
(.122)\end{array}$ & $\begin{array}{l}.145 \\
(.119)\end{array}$ \\
\hline In(Government Spending $\left.{ }_{i}\right)$ & $\begin{array}{l}.018 \\
(.468)\end{array}$ & $\begin{array}{l}1.80^{* * *} \\
(.478)\end{array}$ \\
\hline $\ln \left(\right.$ Tariff $\left._{i j}\right)$ & $\begin{array}{l}.777^{* *} \\
(.310)\end{array}$ & $\begin{array}{l}.014 \\
(.277)\end{array}$ \\
\hline Constant & $\begin{array}{c}-12.9^{* * *} \\
(3.15)\end{array}$ & $\begin{array}{r}-13.1^{* *} \\
(5.06)\end{array}$ \\
\hline Uncensored & & \\
\hline $\begin{array}{l}\text { Observations } \\
\text { Left-Censored }\end{array}$ & 414 & 625 \\
\hline Observations & 703 & 492 \\
\hline Countries & 43 & 43 \\
\hline$p>\chi^{2}$ & 0.0000 & 0.0000 \\
\hline
\end{tabular}

positive result for ISO certifications would suggest that quality NTBs reflect sector-specific consumer concerns. A null result, coupled with significant interest-group variables, would suggest that quality NTBs reflect primarily interest-group pressures.

The model specification for the sectoral analysis is identical to that of the national analysis, with the following exceptions. First, because sectoral NTBs are highly skewed, I $\log$ the dependent variable prior to analysis. For the same reason, all other sectoral variables are logged. Second, because all competitive democracies are GATT members, I omit the GATT dummy from the sectoral analysis. Third, because roughly half of the sectoral NTB observations are zeroes, I employ Tobit rather than OLS regression. Results are shown in Table 4.

Table 4 makes several points. First, three of the four interest-group variables have the predicted effects on quality NTBs: high sectoral employment and import penetration lead to higher protection, while high export dependence leads to lower protection. This indicates that quality NTBs indeed reflect protectionist interest-group demands, although it does not rule out the possibility that they also reflect public pressures. Second, the interest-group variables have similar effects on quality and core NTBs. This reinforces the view that the former, like the latter, reflect protectionist pressures. Finally, ISO certification is insignificant. Because the absence of cross-national, cross-sectoral data make this variable a distant proxy for consumer concerns about product quality, this finding does not prove that such concerns are politically irrelevant. That said, it also provides no evidence that such concerns matter. The strong evidence that interest groups demand quality NTBs, and the absence of evidence that consumers do, suggests that quality NTBs are protectionism in disguise and that their prevalence in democracies owes more to optimal obfuscation than to heightened concerns about public welfare.

\section{CONCLUSION}

A growing number of studies show that democracy promotes trade openness. I argue, in contrast, that democracy has asymmetric effects on different types of protection. It discourages the use of transparent measures such as tariffs but encourages the use of less transparent NTBs. Democracy's net impact on trade policy is thus theoretically unclear.

My tariff results mirror those of previous studies on the democracy-tariff relationship (Milner and Kubota 2005). However, some studies also employ multidimensional trade policy measures: for example, Milner and Kubota employ the dichotomous Sachs-Warner (SW 1995) index, which classifies countries as "closed" if they have average tariff rates of $40 \%$ or more OR core NTB coverage of $40 \%$ or more OR a black-market exchange rate premium of $20 \%$ or more OR a state monopoly on exports OR a socialist economy. They find that, according to this measure, democracies are more open than autocracies. How can we reconcile this finding with my own?

To answer this question, consider what results based on SW do not tell us. As Rodriguez and Rodrik (2000) point out, variation in the multidimensional SW index is driven largely by two components: the blackmarket premium and state export monopolies. In the 1990s, these are virtually the only criteria that classify economies as closed: all but one country in my sample have "open" levels of tariffs and core NTBs. ${ }^{21}$ Results based on SW thus tell us little about democracy's impact on tariffs and core NTBs in the 1990s, because SW captures almost none of the variation in these measures during this period. Such results tell us nothing about democracy's impact on quality NTBs because the latter are not part of the SW index. For these reasons, my findings are consistent with virtually any based on the SW measure. More generally, because components

\footnotetext{
${ }^{21}$ There is, however, tremendous variation among these "open" economies: tariff rates range from $0 \%$ to $39 \%$, core NTB coverage ranges from $0 \%$ to $28 \%$, and quality NTB coverage ranges from $1 \%$ to $39 \%$.
} 
of multidimensional measures may not covary, such measures tell us little about variation in individual components. My results-which concern variation in particular forms of protection-are thus consistent with almost any findings obtained with multidimensional measures (e.g., Frye and Mansfield 2004).

My results beg the question: if democracy reduces some trade barriers but increases others, what are its net effects on trade policy? There is no simple answer to this question because it is difficult to compare different forms of protection. I do not know, for example, whether a $20 \%$ tariff, a VER of 100,000 units, or a requirement that foreign goods meet domestic safety standards is more protectionist. One possible solution to this problem would be to examine the impact of democracy on trade and to assume that trade flows reflect the effects of all types of protection. If so, then the modal finding that democracy boosts trade (Bliss and Russett 1998; Mansfield, Milner, and Rosendorff 2000) suggests that democracy has net liberalizing effects. The problem with this interpretation, however, is that democracy may increase trade directly even if it does not reduce trade barriers. As Bliss and Russett point out, democracy reduces uncertainty in at least two ways. First, democracies are less likely to go to war with one another, thereby reducing the risk that trade will be disrupted by military conflict. Second, because democracies have more checks and balances than autocracies, democratic policy commitments tend to be more credible. Because democratic policies are, for these reasons, less likely to change than autocratic ones, private actors are more likely to establish trade and investment links with democracies than with autocracies.

The point is that policy credibility matters independently of policy content. The mere credibility of democratic policies can promote private trade even if these policies are no more liberal than those of autocracies. This would explain Bliss and Russett's (1998) results, which show that democracy promotes trade even after controlling for (a proxy for) trade policy. A clear implication of this finding is that we cannot infer the effects of democracy on trade policy from its effects on trade flows. Instead, to measure the former effects, we need to develop comparable measures of tariff and NTB protection.

My results have one implication for our understanding of trade policy and two that go beyond the trade policy literature. The first implication is that other de- terminants of trade policy could, like democracy, have asymmetric effects on different policy instruments. For example, other political institutions affect trade policy in the same way that democracy does: by changing politicians' relative responsiveness to mass public and interest-group pressures (Nielson 2003; Rogowski 1987). We might thus expect these institutions to have similarly asymmetric effects on trade policy. Most studies of trade policy, however, examine only a single instrument: either tariffs (McGillivray 1997; Nielson 2003) or NTBs (Busch and Reinhardt 1999; Gawande and Hansen 1999). As a consequence, although we know a lot about the determinants of tariffs and NTBs, we probably know less about the determinants of overall protection.

A second, broader, implication is that, if politicians can craft ever more complex policies, then democracy may lead, not to greater policy transparency, but to greater policy complexity. We must therefore question the conventional wisdom that democracy promotes policy transparency (Bueno de Mesquita et al. 2003; Rosendorff and Vreeland 2004). Less obviously, we must also question the claim that democracy leads to efficient policies (Becker 1983; Wittman 1989), where efficiency means that redistribution is achieved with minimal deadweight loss. Efficient policies are typically simple: it is far more efficient simply to give money to politically important groups than it is, say, to buy grain at guaranteed prices or to build bridges that no one needs. Yet the latter forms of redistribution are ubiquitous in democracies, perhaps because democracy itself makes the former politically unacceptable. Hence, to the extent that democracy promotes obfuscation through the use of complex policies, it may also reduce the efficiency of redistributive transfers.

A final, still broader, implication is that a rise in the political power of mass publics may lead, not to more public-spirited policies, but to policies whose costs are more difficult for publics to discern. This may be true whether public influence stems from electoral reforms, referenda, or a rise in voter turnout. Without an increase in the public's information and sophistication, these improvements in formal representation may simply induce politicians to repackage old policies in new, more attractive forms. My results thus suggest that the informational problems underlying Michels's "iron law of oligarchy" (1915) remain a potent obstacle to democratic representation. 


\section{APPENDIX}

Sample Countries and Years

\begin{tabular}{|c|c|c|c|c|c|}
\hline \multirow[b]{2}{*}{ Country } & \multicolumn{2}{|c|}{ Years } & \multirow[b]{2}{*}{ Country } & \multicolumn{2}{|c|}{ Years } \\
\hline & Tariffs & NTBs & & Tariffs & NTBs \\
\hline Albania & 97 & 97 & Malawi & 98 & 96 \\
\hline Algeria & 93,98 & $92-93,98-99$ & Malaysia & $91,93,97$ & $91,94,96$ \\
\hline Argentina & $93,95,97-00$ & $93,95,97-00$ & Mauritius & 98 & 95 \\
\hline Australia & $93,97-00$ & $93,96,99$ & Mexico & $91,95,97-00$ & $91,95,98-99$ \\
\hline Austria & 93 & 93 & Moldova & 96,00 & 95 \\
\hline Bangladesh & 93-94, 99-00 & $94,98,00$ & Morocco & $93,97,00$ & 99 \\
\hline Belarus & 97 & 96 & Mozambique & 94,97 & 94 \\
\hline Bhutan & 99 & 99 & Nepal & 93,00 & 93,98 \\
\hline Bolivia & 93, 95, 97-99 & $95,98-99$ & New Zealand & $93,95-96,98-00$ & $93,96,99$ \\
\hline Brazil & $93,95,97-00$ & $93,95,97-99$ & Nicaragua & $95,98-00$ & 93 \\
\hline Cameroon & 95,97 & 95,97 & Nigeria & 92,95 & 92,94 \\
\hline Canada & $93,95,97-00$ & $93-94,96,99-00$ & Norway & $93,95-96,98,00$ & $93,94,96$ \\
\hline Cent. Af. Republic & 97 & 97 & Oman & 92 & 92,99 \\
\hline Chad & 97 & 97 & Paraguay & $91,95,97-00$ & $93,95,98-99$ \\
\hline Chile & $91,95,97-00$ & 91, 94, 97-99 & Philippines & $95,98-00$ & 94,98 \\
\hline China & $93,95,97-98$ & $93-94,97$ & Papua New Guinea & 97 & 97 \\
\hline Costa Rica & $95,99-00$ & 98 & Poland & $91,95-96,00$ & 94,99 \\
\hline Czech Republic & $92-93,96,99$ & $91,92,99$ & Russia & $93-94,97$ & 94 \\
\hline Ecuador & $93,95,97-99$ & $95,98-99$ & Saudi Arabia & $91,94,99-00$ & $94,95,99$ \\
\hline Egypt & 95,98 & 99 & Singapore & $94-95,98-99$ & 92,94 \\
\hline El Salvador & $95,98,00$ & 97 & Slovenia & 99 & 99 \\
\hline Estonia & 95 & 96 & South Africa & $93,96-97$ & $91,94,99$ \\
\hline Ethiopia & 95 & 95 & South Korea & $92,95,96,99$ & $92,95-96$ \\
\hline Finland & 93 & 93 & Sri Lanka & $93-94,97,00$ & $93-94$ \\
\hline Ghana & 93 & 95 & Sweden & 93 & 93 \\
\hline Guatemala & $95,98,00$ & 98-99 & Switzerland & $93,96,98-00$ & 93,96 \\
\hline Honduras & $95,99-00$ & 98 & Tanzania & $94-98-00$ & 93 \\
\hline Hungary & $92-93,96-97$ & $92-93,97,99$ & Thailand & $91,95,00$ & 91,94 \\
\hline Iceland & 93,96 & 93,96 & Trinidad \& Tobago & $91-92,96,99$ & 92 \\
\hline India & $92,97,99$ & 92,97 & Tunisia & $92,95,98$ & $92,95,99$ \\
\hline Indonesia & 95-96, 99-00 & $94,97,99$ & Turkey & 93,97 & 94,97 \\
\hline Japan & $93,95-96,98-00$ & $93,95-96$ & Uganda & 94,00 & 93 \\
\hline Kazakhstan & 96 & 99 & Uruguay & $92,95,97-00$ & $95,98-99$ \\
\hline Kenya & $90,94,00$ & 93 & United States & $93,95-96,98-00$ & $93-94,96,99$ \\
\hline Kyrgyzstan & 95 & 98 & Venezuela & $92,95,97-00$ & $92,95,98-99$ \\
\hline Latvia & 97 & 96 & Zambia & 93,97 & 93 \\
\hline Lithuania & 97 & 97,99 & Zimbabwe & 98 & 97 \\
\hline Madagascar & 95 & 95 & & & \\
\hline
\end{tabular}

\section{REFERENCES}

Adsera, Alicia, and Carles Boix. 2002. "Trade, Democracy, and the Size of the Public Sector." International Organization 56 (Spring): 229-62.

Baba, Stephen Anthony. 1997. "Democracies and Inefficiency." Economics and Politics 9 (July): 99-114.

Baker, Andy. 2003. "Why Is Trade Reform so Popular in Latin America? A Consumption-Based Theory of Trade Policy Preferences." World Politics 55 (April): 423-55.

Becker, Gary S. 1983. "A Theory of Competition Among Pressure Groups for Political Influence." Quarterly Journal of Economics XCVII (August): 371-400.

Bliss, Harry, and Bruce Russett. 1998. "Democratic Trading Partners: The Liberal Connection, 1962-1989." The Journal of Politics 60 (November): 1126-47.

Bueno de Mesquita, Bruce, Alastair Smith, Randolph M. Siverson, and James D. Morrow. 2003. The Logic of Political Survival. Cambridge, MA: MIT Press.

Budge, Ian, Hans-Dieter Klingemann, Andrea Volkens, Judith Bara, and Eric Tanenbaum. 2001. Mapping Policy Preferences: Estimates for Parties, Electors, and Governments 1945-1998. New York: Oxford University Press.
Busch, Marc L., and Eric Reinhardt. 1999. "Industrial Location and Protection: The Political and Economic Geography of U.S. Nontariff Barriers." American Journal of Political Science 43 (October): 1028-50.

Cassing, James, Timothy J. McKeown, and Jack Ochs. 1986. "The Political Economy of the Tariff Cycle." American Political Science Review 80 (September): 843-62.

Feenstra, Robert C. 2000. World Trade Flows, 1980-1997. CD-ROM. Davis, CA: Institute of Governmental Affairs.

Frankel, Jeffrey A., and David Romer. 1999. "Does Trade Cause Growth?" American Economic Review 89 (June): 379-99.

Frye, Timothy, and Edward D. Mansfield. 2004. "Timing Is Everything: Elections and Trade Liberalization in the Postcommunist World." Comparative Political Studies 37 (May): 37198.

Gawande, Kishore, and Wendy L. Hansen. 1999. "Retaliation, Bargaining, and the Pursuit of 'Free and Fair' Trade." International Organization 53 (Winter): 117-59.

Gilligan, Michael J. 1997. Empowering Exporters: Reciprocity, Delegation, and Collective Action in American Trade Policy. Ann Arbor: University of Michigan Press.

Grossman, Gene M., and Elhanan Helpman. 1994. "Protection for Sale.” American Economic Review 84 (September): 833-50. 
Herrman, Richard K., Philip E. Tetlock, and Matthew N. Diascro. 2001. "How Americans Think About Trade: Reconciling Conflicts Among Money, Power, and Principles.” International Studies Quarterly 45 (June): 191-218.

International Monetary Fund (IMF). 2005. "Dealing with the Revenue Consequences of Trade Reform." Paper prepared by the Fiscal Affairs Department.

Keele, Luke J., and Nathan J. Kelly. 2006. "Dynamic Models for Dynamic Theories: The Ins and Outs of Lagged Dependent Variables." Political Analysis 14 (Spring): 186-205.

Khattry, Barsha, and J. Mohan Rao. 2002. "Fiscal Faux Pas?: An Analysis of the Revenue Implications of Trade Liberalization." World Development 30 (August): 1431-44.

Lee, Jong-Wha, and Phillip Swagel. 1997. "Trade Barriers and Trade Flows Across Countries and Industries." Review of Economics and Statistics 79 (August): 372-82.

Magee, Stephen P., William A. Brock, and Leslie Young. 1989. Black Hole Tariffs and Endogenous Policy Theory: Political Economy in General Equilibrium. New York: Cambridge University Press.

Mansfield, Edward D., and Marc L. Busch. 1995. "The Political Economy of Nontariff Barriers: A Cross-National Analysis." International Organization 49 (Autumn): 723-49.

Mansfield, Edward D., Helen V. Milner, and Peter Rosendorff. 2000. "Free to Trade: Democracies, Autocracies, and International Trade." American Political Science Review 94 (June): 305-22.

Mansfield, Edward D., Helen V. Milner, and Peter Rosendorff. 2002. "Why Democracies Cooperate More: Electoral Control and International Trade Agreements." International Organization 56 (Summer): 477-514.

McGillivray, Fiona. 1997. "Party Discipline as a Determinant of the Endogenous Formation of Tariffs." American Journal of Political Science 41 (April): 584-607.

Michels, Robert. 1915, reprinted 1949. Political Parties: A Sociological Study of the Oligarchical Tendencies of Modern Democracy. Glencoe, IL: Free Press.

Milner, Helen V., and Benjamin Judkins. 2004. "Partisanship, Trade Policy, and Globalization: Is There A Left-Right Divide on Trade Policy?" International Studies Quarterly 48 (March): 95-120.
Milner, Helen V., and Keiko Kubota. 2005. "Why the Move to Free Trade? Democracy and Trade Policy in the Developing Countries." International Organization 59 (Winter): 107-44.

Nielson, Daniel L. 2003. "Supplying Trade Reform: Political Institutions and Liberalization in Middle-Income Presidential Democracies." American Journal of Political Science 47 (July): 470-91.

Plume, Janet. 1996. "Trade Pacts Leave a Bitter Taste." Journal of Commerce (February): 7A.

Polachek, Solomon W. 1980. "Conflict and Trade." Journal of Conflict Resolution 24 (March): 57-78.

Ray, Edward J. 1981. "The Determinants of Tariffs and Nontariff Trade Restrictions in the U.S." Journal of Political Economy 89 (February): 105-21.

Rodriguez, Francisco, and Dani Rodrik. 2000. "Trade Policy and Economic Growth: A Skeptic's Guide to the Cross-National Evidence." In NBER Macroeconomics Annual 2000. ed. Ben Bernanke and Kenneth Rogoff. Cambridge, MA: MIT Press.

Rogowski, Ronald. 1987. "Trade and the Variety of Democratic Institutions." International Organization 41 (Spring): 203-23.

Rose, Andrew K. 2004. "Do WTO Members Have More Liberal Trade Policy?" Journal of International Economics 63 (July): 20935.

Rosendorff, B. Peter, and James Raymond Vreeland. 2004. "Democracy and Data Dissemination: The Effect of Political Regime on Transparency." Working Paper.

Sachs, Jeffrey D., and Andrew Warner. 1995. "Economic Reform and the Process of Global Integration." Brookings Papers on Economic Activity 1995 (1): 1-118.

Todd, Chuck. 2004. "Campaign by the Numbers." The New York Times (3 November): p. A19.

Trefler, Daniel. 1993. "Trade Liberalization and the Theory of Endogenous Protection: An Econometric Study of U.S. Import Policy." The Journal of Political Economy 101 (February): 13860.

The White House. 1996. "A National Security Strategy of Engagement and Enlargement."

Wittman, Donald. 1989. "Why Democracies Produce Efficient Results.” Journal of Political Economy 97 (December): 1395-424. 